\begin{tabular}{|ll|}
\hline & $\begin{array}{l}\text { International Journal of Advanced Engineering, Management } \\
\text { and Science (IJAEMS) } \\
\text { ISSN: 2454-1311 } \\
\text { Vol-7, Issue-1; Jan, } 2021 \\
\text { INF }\end{array}$ \\
& $\begin{array}{l}\text { Journal Home Page Available: } \text { https://ijaems.com/ } \\
\text { Journal DOI: } \text { https://dx.doi.org/10.22161/ijaems } \\
\text { Article DOI: } \text { https://dx.doi.org/10.22161/ijaems.71.6 }\end{array}$ \\
\hline
\end{tabular}

\title{
Impact and Coping Mechanism of Restaurant Business Amidst Covid-19 Global Pandemic
}

\author{
Aileen Y. Vigilia, Hernan V. Portana, Sherwin B. Santos, Ruth Job L. Salamanca, Kathreen \\ Marie P. dela Cruz
}

Received: 18 Nov 2020; Received in revised form: 05 Jan 2021; Accepted: 18 Jan 2021; Available online: 27 Jan 2021 (C)2021 The Author(s). Published by Infogain Publication. This is an open access article under the CC BY license (https://creativecommons.org/licenses/by/4.0/).

\begin{abstract}
The study explored the impact of the covid-19 pandemic in the restaurant business in the City of Cabanatuan, Province of Nueva Ecija, Philippines. It also included the coping mechanism they instituted amidst the situation. The sample size consisted of 36 restaurants and eateries. Descriptive research design was used. Results revealed the closure of small restaurants, sales tremendously decreased, loss of income and jobs, loan obligation defaults, and state of mind of its stakeholders. Coping mechanism included the use of massive online advertisements to market the product, selling of ready-to-cook raw materials, shifting and reduced employee work hours, and the use of delivery services. Other problems consisted of unsustained product quality standards, the escalating price of raw materials, and at times unreasonable delivery fees of food couriers.
\end{abstract}

Keywords - COVID-19, coping mechanism, impact, online advertisement, restaurant business.

\section{INTRODUCTION}

The restaurant business is one of the worst-hit industries due to Covid-19 not only in the Philippines but the whole world. Many of the restaurants were on the brink of closure, there were some who managed to survive, but in limited operations. As continuously reported and confirmed that COVID-19 cases soared in February and March 2020, a greater share of restaurant operators reported lower sales as compared in the same period of 2019 and the previous years.

On February 28, Roslyn Stone quoted in Restaurant Business, the $\mathrm{COO}$ is the one who gave a response in times of crisis like this global pandemic CIVID-19. She quoted that this global pandemic had a great impact in spreading the virus in the restaurants and makes it possible for the employees to carry the said virus, that reason that needs for the fast recovery for the restaurant business manpower operation (Maze \& Heather, 2020).

On March 15, 2020, the Philippine President Rodrigo Duterte also ordered a lockdown just like the other countries infected and at high risk of confirmed cases of COVID 19. All restaurants, bars, amusement parks, and even churches were closed to stop the transmission of said virus.

Despite the restaurant business' being rocked by a dramatic decline in sales, the owners/operators still found ways to cope up even to support the day-to-day operational needs and employees' wages. Nearly all employers are aware of the challenges and have established policies to help, but they are finding it hard to execute their diversity, equity, and inclusion strategies (Mckinsey \& Company, 2020).

Many restaurants business feels suffocated due to COVID-19 resulting to stop business operation, no income, a layoff of workers, while others depended on the government support.

According to Nurin, usual funding from the bank was always in favor only to the large restaurants and nations. The majority of the bank fund providers were given consideration to the large restaurants. Only 5\% of small and independent restaurants were receiving fund assistance. 
Just like the restaurant business in Cabanatuan City, Nueva Ecija, Philippines, many of them have decided to close the business permanently or temporarily because of the current situation of the Covid 19 pandemic. Other restaurants, however, found ways to be more resilient in their approach to the situation as they could not afford to lose their source of livelihood primarily because they have mortgaged their property to the banks.

One of the restaurant business owners said that "our restaurant is reinforcing relationships and dedication for the products and services that we provided. We promote our business by simply touching our neighbors and giving promos via any online means to overcome challenges especially in this trying time of Covid 19 pandemic", (Shaffer, 2020).

Restaurants, in particular, have faced a massive disruption to their income streams and business models. Many have had to stop allowing sit-down customers, pivoting to offer only takeout or delivery services. There was a widespread closure of the restaurant business, and one of the reasons is a lack of supplier affected by certain food brands and one of the examples is the coca-cola company that decreased their net revenues (Wiener-Bronner, 2020).

On the concerns related to the business operational continuity for all members of the organization, employee protection, and market preservation are the top priorities. Given the fact that the COVID-19 pandemic contains a very tremendous impact on restaurant business operation. And for fast recovery, business operators invest in strategic, operational, and financial resilience, (Bingham and Hariharan, 2020).

The study aims to assess the impact of the pandemic and their coping mechanism. Specifically, this research described: the impact of the Covid-19 pandemic on the restaurant business in Cabanatuan City, Province of Nueva Ecija, Philippines; and the coping mechanism and problems of the food establishments amidst the covid-19 pandemic.

\section{METHODOLOGY}

The study was used the descriptive survey research design with 36 restaurant operators considered as the respondents of the study. Purposive sampling was employed due to ongoing movement and quarantine restrictions being imposed by the Philippine government. The study further utilized the unstructured interview in order to elicit the actual condition of the business. Simple descriptive statistics were used for its data analysis.

\section{RESULTS AND DISCUSSION}

\section{Impact of Covid-19 on restaurant business in Cabanatuan City}

All or $100 \%$ of the respondents said that the COVID-19 pandemic was affected by the covid-19 pandemic. Many $(36 \%)$ in the restaurant sector closed except for the major players (64) in the industry that included fast-food chains and known homegrown restaurants. Those that belong to $36 \%$ were small eateries or the more popular "carinderias" in the Philippines that sell affordable viands sans the formal setting. Understandably, this is bound to happen because they cater to the office and mall employees where both were downsized in number because of the quarantine policies and limited movement of people in order to stop the transmission of the covid-19 virus.

The same figure $(100 \%)$ suffered sales losses by as much as $80-90 \%$. This also meant loss of income; hence, hurting the workforce either through job termination, shifting, and fewer work hours available. This was partly the offshoot of transport restriction because of the ongoing lockdown.

Few (23\%) have indicated, divulged rather, during the survey they have loan obligation with financing institutions. They further disclosed that their operation has suffered much because of the current situation. Only three (8.33\%) complained they have already accumulated amortization defaults.

Other than these, tremendous anxiety, fear, and stress have become prevalent not only to owners/operators of the restaurant business but to their employees as well.

\section{Coping mechanism of the owners/operators}

Because the limitations in gatherings to a certain number of people have considerably affected dine-in restaurants. Since quarantine level was not to be lifted yet until a vaccine is discovered that restaurants are kept hanging on to the point of nowhere. Until such time (which took a month or so) that they began (1) massive online delivery food services to the point where they have to (2) offer ready-to-cook raw materials, (3) pick up or delivery via food couriers, but the latter option is either for a fee or part of their promo. They have also scheduled (4) shifting of employee duties instead of laying them off. All the mentioned marketing strategies can only reach the customers thru the creation of (5) FaceBook pages and other online platforms currently available which were seldom used in the past.

Consequently, these alternative approaches would mean resiliency especially on the part of the restaurant business. 
The strategies used may be commendable if just to keep these restaurants afloat and improve their cash flows however, these are without problems as observed by the researchers namely (1) the tendency to raise the price of the products more particularly notable in small-scale eateries which they claimed to be blamed on distorted supply-chain of raw materials because of movement restrictions being imposed by the government, (2) quality control of products being delivered compromised, (3) loss of jobs for the majority of its workers. Note that the researchers could neither attest nor verify the disclosure of informants especially the practice of work shifts they impose on their employees, and (4) exorbitant fees, rather debatable rates charged on delivery services being charged by food couriers.

\section{CONCLUSIONS AND RECOMMENDATIONS}

Covid-19 pandemic has a great impact not only on the restaurant business but as well to its stakeholders. The coping mechanism instituted by the restaurant sector was varied especially focused on maintaining or cutting their further losses by using multi-media, online food deliveries, and offer ready-to-cook raw materials... just to offset operational losses and support the well-being of its employees.

Problems include loss of jobs and income, spiraling prices of offered products, unattended quality control, and high cost of deliveries.

The researchers recommend the following:

1. For homegrown or local restaurants (other than known fast-food chains that have alternatives currently in place) to diversify their business operation attuned to the needs of the present situation to support and enhance (Vertudes, Musa, Cosilet, Salagubang \& Balaria, 2020) the livelihood of their displaced workers.

2. For this sector to continuously uphold the rights of its workers like giving a separation pay or an amount the business can afford.

3. For this sector to be more prudent in its pricing, practice to the fullest the spirit of corporate social responsibility (Mina, et.al.,2019), and check on its quality standards at all times while creating a response plan for its complaints.

4. For this sector to maximize its operational capacities to reach a wider customer base not only of Filipino businessmen but for every slipper entrepreneur in the world (Mina, et.al, 2020).

5. For other delivery service/s to enter the market to level the playing field and thus, encouraging competition; so that people may have choices of affordable service.

6. For banks and financing institutions that may have extended credit to the restaurant, the sector may further relax the terms

a. Condonation of penalty charge on overdue amortizations (other than the guidelines set forth by the Inter-Agency Task Force (IATF);

b. Restructure the loan for a longer term that will depend on the operation's cash flows;

c. Extend additional capital to offset previous losses, or as the case may be.

7. For this sector to consider nutritious food value, efficient delivery while practicing food safety and hygiene.

8. For this sector to attend to the emotional and mental health of its stakeholders via guidance or counseling, and finally orienting them to the" new normal".

\section{REFERENCES}

[1] Aljazeera (2020) Duterte reimposes coronavirus lockdown as he criticizes doctors. Aljazeera. August 3, 2020 https://www.aljazeera.com/news/2020/8/3/duterte-reimposescoronavirus-lockdown-as-he-criticises-doctors

[2] Asia Pacific (2020) More afraid of hunger: COVID-19 rules causing many in Philippines to starve. December 9, 2020 https://www.japantimes.co.jp/news/2020/12/09/asiapacific/philippines-covid19-hunger/

[3] Associated Press (2020) Philippine President Imposes Travel Limits, Quarantines. March 12, 2020

https://www.voanews.com/science-health/coronavirusoutbreak/philippine-president-imposes-travel-limitsquarantines

[4] Baes, P. (2020) The Past, Present, and Future of Dining in Metro Manila. June 14, 2020. Spot.ph

https://www.spot.ph/eatdrink/the-latest-eatdrink/82427/restaurants-metro-manila-after-covid-19-a328420200614-lfrm4

[5] Calimon, D. (2020) Philippines: Enhanced Community Quarantine. Global Compliance News. April 24, 2020 https://globalcompliancenews.com/enhanced-communityquarantine-ph-covid19-25032020/ 
[6] CNN Philippines (2020) IATF OKs reopening restaurant dine-in under GCQ areas. June 11, 2020 https://www.cnnphilippines.com/news/2020/6/11/GCQMetro-Manila-Cebu-restaurant-dine-in-COVID-19.html

[7] Center for Disease Control and Prevention (2020) Restaurants \& Bars, December 16, 2020 https://www.cdc.gov/coronavirus/2019ncov/community/organizations/business-employers/barsrestaurants.html

[8] Cornell University (2020) Reopening Restaurants After COVID-19: Lessons From Asia, December 8, 2020 https://events.cornell.edu/event/reopening_restaurants_after_c ovid-19_lessons_from_asia

[9] Dancel, R. (2020) Coronavirus:Duterte places a third of the Philippines on sweeping lockdown. The Straits Times. March 23, 2020

https://www.straitstimes.com/asia/se-asia/coronavirusmassive-cracks-in-manila-lockdown-luzon-under-enhancedcommunity-quarantine

[10] Enderun ( ) What is the Future of Restaurants in this COVID19 Era? Here's What the Industry Experts Think. May 3, 2020

https://www.enderuncolleges.com/news/what-is-the-futureof-restaurants-in-this-covid-19-era-heres-what-the-industryexperts-think/

[11] Kabagani, LJ (2020) Makati sets guidelines for food establishments, safe dining. Phil. News Agency. August 20, 2020

https://www.pna.gov.ph/articles/1112899

[12] Lim Uy, S. (2020) Through COVID-19, top Philippine restaurants just want to survive. Rappler. Nov. 5, 2020 https://www.rappler.com/life-and-style/food-drinks/topphilippines-restaurants-just-want-survive

[13] Mae Flor Vertudes, Christopher Dave Musa, Mary Ann Cosilet, Rommel Salagubang, Felipe Balaria(2020).Impact of Rice Tariffication Law in selected Rice Farmers in Nueva Ecija, Philippines. International Journal of Advanced Engineering, Management and Science(ISSN: 24541311),6(3), 147-153. http://dx.doi.org/10.22161/ijaems.63.7

[14] Mina, J., Subia, G. \& Ermita, P. (2020). Value Chain Analysis of Slipper Industry in the Footwear Capital of the North. International Journal of Supply Chain Management. Volume 9, Issue 5, 178-183.

[15] Mina, J.C., Barlis, P.T., Vega, N.C. and Subia, G.S. (2019) Corporate Social Responsibilities of Selected Resorts in Cabanatuan City, Nueva Ecija, Philippines. Open Access Library Journal, 6: https://doi.org/10.4236/oalib.1105292

[16] Reuters (2020) As economy slumps, Philippines lets eateries reopen to recoup job losses. June 16, 2020 https://www.reuters.com/article/us-health-coronavirusphilippines-restau-idUSKBN23N20T
[17] Reyes, M. (2020) Forest House, People's Palace, Lotus Court And More: COVID-19 Has Closed F\&B Favourites Around The Philippines. Tatler Philippines. July 21, 2020 https://ph.asiatatler.com/dining/forest-house-peoples-palacethai-lotus-court-and-more-a-look-back-into-these-iconicrestaurants-that

[18] Salcedo, M. (2020) Restaurants stay strong amid COVID-19. Philippine daily Inquirer. March 15, 2020 https://business.inquirer.net/292601/restaurants-stay-strongamid-covid-19

[19] Sanchez, MJ. (2020) Main reasons for increasing orders through food delivery apps during the COVID-19 pandemic in the Philippines as of June 2020. Statista. August 11, 2020 https://www.statista.com/statistics/1147540/philippinesreasons-for-increasing-orders-from-food-delivery-appsduring-covid-19/

[20] Scattergood, G. (2020) More afraid of hunger: COVID-19 rules causing many in Philippines to starve. Food-Navigator Asia.com. Dec. 2020

https://www.foodnavigatorasia.com/Article/2020/03/24/COVID-19-and-APAC-s-foodand-beverage-sector-All-our-coronavirus-news-in-one-place

[21] Score (2020) How to Reopen Your Restaurant After the Coronavirus Shutdown... and Stay Open, May 28, 2020 https://www.score.org/resource/how-reopen-your-restaurantafter-coronavirus-shutdown-and-stay-open

[22] SGS (2020) Navigating the Impact of Covid-19 on the Food Industry. May 4, 2020 https://www.sgs.ph/en/news/2020/05/navigating-the-impactof-covid-19-on-the-food-industry

[23] WHO (2020) Coronavirus disease (COVID-19): Food safety and nutrition, August 14, 2020 https://www.who.int/emergencies/diseases/novelcoronavirus-2019/question-and-answers-hub/q-adetail/coronavirus-disease-covid-19-food-safety-andnutrition\#: :text=delivery 